\title{
Genotype $\times$ Environment Interactions in Conventional versus Pasture-Based Dairies in Canada
}

\author{
P. J. Boettcher, ${ }^{* 1}$ J. Fatehi, ${ }^{*}$ and M. M. Schutz† \\ ${ }^{*}$ Centre for Genetic Improvement of Livestock \\ Department of Animal and Poultry Science, \\ University of Guelph, Ontario, Canada N1G 2W1, \\ †Department of Animal Science \\ Purdue University, West Lafayette, IN 47901
}

\section{ABSTRACT}

The objective of this study was to evaluate effects of genotype $\times$ environmental interaction $(\mathrm{G} \times \mathrm{E})$ on dairy traits among herds in Canada that practice intensive rotational grazing versus conventional methods that rely on stored feeds. Based on responses to questionnaires, 22 herds were selected for the grazing group and the conventional group consisted of 34 large freestall dairies. Production data consisted of 6749 lactations of 2817 cows in the grazing herds and 29,371 lactations of 12,774 cows in the control herds. Subsets of data for reproduction and conformation also were created. Per cow production was greater in the conventionally managed herds (9947 kg of milk) than in the grazing herds $(9400 \mathrm{~kg})$. Phenotypic data were regressed on sire predicted transmitting abilities (PTA) and genetic correlations for all traits were estimated between environments. A scaling effect was observed across environments for yield traits, as phenotypic differences among cows were greater than predicted by sire PTA in conventional herds and consistent with sire PTA in grazing herds. Heritabilities for yield also were greater in conventional herds. Other effects of $\mathrm{G} \times \mathrm{E}$ were minor, with genetic correlations of near 0.90 or greater for all traits. Among yield traits, genetic correlation was lowest for fat $(0.88$ with $\mathrm{SE}=0.04)$. These results demonstrate that effects of $\mathrm{G} \times \mathrm{E}$ are small between the two types of management systems analyzed and that graziers can accurately select sires based on national rankings.

(Key words: genetics, grazing, sire evaluation)

Abbreviation key: 305ME $=305-d$ mature equivalent, $\mathbf{C I}=$ calving interval, $\mathbf{G} \times \mathbf{E}=$ genotype $\times$ environmental interaction.

Received October 22, 2001.

Accepted December 11, 2001.

Corresponding author: P. J. Boettcher; e-mail: paulboettcher@ anafi.it.

${ }^{1}$ Current address: ANAFI, Via Bergamo 292, 26100 Cremona, Italy.

\section{INTRODUCTION}

Accurate genetic evaluation of animals on a national basis requires consistency of sire ranking across all environments. Differences between sires in the genetic ability of their daughters to perform in different environments may result from interactions between genotype and environment $(\mathbf{G} \times \mathbf{E})$ [e.g., Cienfuegos-Rivas et al. (1999)]. Within Canada, many of the nongenetic factors that may influence production are similar across the country. Most of the dairies are situated in the southern part of the country. Although coastal areas have warmer winters than the inland regions, the climate is similar across the major dairy producing areas. Seasons of the year are very distinct, but heat stress is not a serious problem in the summer, and housing moderates the effects of winter cold. Milk marketing systems are similar, as a supply management system exists nationally, which poses obstacles for such practices as seasonal calving and production of milk for specialized dairy foods.

One factor that could cause $\mathrm{G} \times \mathrm{E}$, however, is differences in feeding and management systems, in particular between herds that practice rotational grazing in the warm months versus herds that confine their cattle for the entire year. Despite the cold winters and short growing season, a small number of Canadian producers practice rotational or managed intensive grazing. Intensive rotational grazing and confinement feeding and management are different environments, and genetic evaluations of sires with daughters primarily in one environment may not be adequate predictors of progeny performance in another environment. In confinement systems, the ideal cows are those that produce the most milk with maximal energy inputs, while under pasture based systems the optimal genotypes are those that produce moderately high levels of milk given somewhat limited energy inputs. Records of cows from confinement systems dominate current genetic evaluations and selection decisions within the Canadian Holstein population. 
Recent studies using data from different countries have shown evidence for $\mathrm{G} \times \mathrm{E}$ between grazing and conventional feeding systems. For example, Weigel et al. (2001) used lactation records and a sire model to estimate the genetic correlations of milk production across 17 countries. The correlation of milk yield in New Zealand (where grazing is nearly exclusively practiced) was only 0.89 and 0.88 with Canada and the US, respectively, versus 0.95 between the US and Canada. For comparison, the correlation was 0.96 between New Zealand and Australia (where grazing is practiced more commonly than in North America).

Some producers who use intensive grazing have become concerned that the current system does not produce and rank bulls adequately for their needs and have begun to use bulls proven in other countries (such as New Zealand), herd bulls, or crossbreeding. Recent studies (Weigel et al., 1999; Kearney et al., 2001a, 2001b) have examined records from grazing and conventionally managed herds in the United States and have concluded that effects of $\mathrm{G} \times \mathrm{E}$ on accuracy of sire rankings were not great enough to warrant a separate selection program directed toward graziers. The objective of this study was to evaluate effects of $\mathrm{G} \times \mathrm{E}$ on dairy traits among herds in Canada that practice intensive rotational grazing versus conventional methods that rely on stored feeds. Because of the importance of type traits in Canada (Canadian Dairy Network, 2001) in addition to production traits, effects of $\mathrm{G} \times \mathrm{E}$ for conformation were also examined.

\section{MATERIALS AND METHODS}

The first and perhaps most critical step in this study was to identify a group of herds in Canada that practice intensive grazing. A list of potential herds was identified based on contacts with dairy extension personnel, university professors, milk recording supervisors, semen salespeople, and from membership lists of grazing interest groups. A questionnaire was drawn up to ask breeders about their feeding, general management, and breeding practices. The questionnaire first asked the breeders to state the usual starting and ending dates of their grazing seasons and the proportion of the total forage provided by pasture during this period. In addition, breeders were asked whether supplemental grain was fed to cows on pasture. Finally, breeders were asked to identify the breeds of their cattle and whether their herds had recorded pedigrees and were enrolled in DHIA. The questionnaire was sent to 69 different herd owners, and 48 responses were received. Based on the responses, 22 herds were selected for the grazing group. These herds were required to intensively graze their cattle for at least 6 mo per year, during which pasture provided at least $70 \%$ of the forage in the cows' diets. In addition, herds were required to be enrolled in DHI and to record pedigree data. All herds provided supplemental grain during the pasture season, but this factor was not considered in the selection process. All herds were in either Nova Scotia or Ontario.

A control (conventional) group consisted of 34 large (>100 cows) free-stall operations in the same two provinces. The decision to use large free-stall herds for the comparison group was based on a number of factors. First, although these herds may not represent the present typical Canadian herd, the number of such herds in Canada (and particularly the number of cows in such herds) is continually increasing. Thus, these herds were expected to be more representative of the future typical herd in Canada. Second, these types of herds are now being targeted by AI companies for their progeny test programs (Welper, 2000), meaning that many of the future breeding decisions for the Canadian dairy population will be made based on phenotypes expressed in this type of environment. Finally, we expected that this type of comparison would have the greatest potential to reveal effects of $\mathrm{G} \times \mathrm{E}$. The herds from Ontario in the conventional group had previously participated in a study on clinical lameness (Boettcher et al., 1998) and were chosen for this study because the authors were familiar with their management practices. In addition, the 10 largest free-stall herds in Nova Scotia were chosen to complete the conventional group. As a result of the requirement for pedigree data, all herds in both groups had registered Holsteins. Effects of $\mathrm{G} \times \mathrm{E}$ were studied for three types of traits: 1) production, 2) reproduction, and 3) conformation.

\section{Production}

For production, traits of primary interest were yields of milk, fat, and protein, but percentages of fat and protein were also considered in some of the analyses. Data were 305-d mature equivalent (305ME) DHI records from 1990 and later and included 6749 lactations from 2817 cows in the grazing herds and 29,371 lactations from 12,774 cows in the control herds. The number of records per cow was approximately the same in both groups, suggesting that longevity and culling rates were similar across environments.

To investigate $\mathrm{G} \times \mathrm{E}$, two approaches were taken for production traits. The first approach tested for a scaling effect on yield traits, such as that observed by Veerkamp et al. (1995), in which the phenotypic differences in production of cows of differing genetic values varied according to the environment. To test for such a scaling effect, herds were separated into grazing and conventional groups and first lactation records of cows in each 
group $(\mathrm{n}=2177)$ for grazing herds and 9502 for conventional) were regressed on the PTA of their respective sires. Significant differences between environments in the regression coefficients for PTA were assumed to indicate a scaling effect associated with the different environments. Weigel et al. (1999) applied a similar approach to production records from grazing and conventional herds in Wisconsin.

The model equation for this analysis was:

$$
\mathrm{y}_{\mathrm{ijk}}=\mathrm{HYS}_{\mathrm{i}}+\mathrm{A}_{\mathrm{j}}+\beta \mathrm{PTA}_{\mathrm{k}}+\mathrm{e}_{\mathrm{ijk}},
$$

where, $\mathrm{y}_{\mathrm{ijk}}=305 \mathrm{ME}$ record for milk, fat, or protein yields of cow $\mathrm{k}$, calving at age $\mathrm{j}$, in herd-year season $\mathrm{i}$; HYS $_{i}=$ fixed effect of $i^{\text {th }}$ herd-year-season (4 seasons per year); $A_{j}$ fixed effect of $j^{\text {th }}$ age group $(j=1,4) ; \beta$ coefficient of regression of the production record on the PTA of the sire of cow $\mathrm{k}$; and $\mathrm{e}_{\mathrm{ijk}}=$ random residual. In theory, $\beta$ is expected to be approximately 1 , under the assumption that the PTA represents the true transmitting ability of each bull. The PTA were one half times EBV from the May 2001 Canadian genetic evaluation.

A second analysis of the data was undertaken to examine whether yields of milk, fat, and protein, and percentages of fat and protein were actually different genetic traits in the grazing and conventional environments. This hypothesis was analyzed by estimating the genetic correlation between records for each trait expressed under the two different environmental conditions. Correlations significantly less than 1.0 were assumed to indicate $\mathrm{G} \times \mathrm{E}$ and statistically significant correlations $<0.80$ were assumed to indicate biologically important $\mathrm{G} \times \mathrm{E}$ (Robertson, 1959). Therefore, each cow had the information reported for a given trait in one environment and missing for the other. The genetic relationships from common sires was used to obtain the correlations. Among cows in the grazing herds, 83\% had at least one paternal-half sib among the cows in the conventional group and $68 \%$ of the cows in the conventional herds had half-sibs in the grazing herds. The relationship matrix was constructed by tracing pedigrees for three generations.

A bivariate animal model with repeated records was assumed to describe the data. The model equation for this analysis was,

$$
\mathrm{y}_{\mathrm{ijkt}}=\mathrm{HYSP}_{\mathrm{i}}+\mathrm{PA}_{\mathrm{j}}+\mathrm{A}_{\mathrm{kt}}+\mathrm{PE}_{\mathrm{k}}+\mathrm{e}_{\mathrm{ijk}},
$$

where $y_{i j k t}=305 \mathrm{ME} \mathrm{milk}$, fat, or protein, or fat or protein percentage for cow $\mathrm{k}$ in environment $\mathrm{t}$, herd-year-season-parity group $\mathrm{i}$ and parity-age group $\mathrm{j} ; \mathrm{HYSP}_{\mathrm{i}}=$ fixed effect of herd-year-season-parity (first or later) $\mathrm{i} ; \mathrm{PA}_{\mathrm{j}}=$ the fixed effect of the parity-age of calving group $\mathrm{j}$ ( 4 age groups in 3 parity groups, first, second, and later);
$\mathrm{A}_{\mathrm{kt}}=$ the random additive genetic effect of cow $\mathrm{k}$ in environment $\mathrm{t} ; \mathrm{PE}_{\mathrm{k}}=$ the random permanent environmental effect of cow $\mathrm{k}$; and $\mathrm{e}_{\mathrm{ijk}}=$ random residual. Variance components were estimated by REML using the VCE 4.0 software of Groeneveld and Garcia-Cortes (1998).

\section{Reproduction}

For reproduction, effects of $\mathrm{G} \times \mathrm{E}$ were examined for calving interval (CI). The CI for a given lactation was simply recorded as the difference in days from the date of calving for that lactation and the following date of parturition. Because some cows did not have a subsequent calving (due to culling or censoring) the dataset included fewer records than had been available for production. In addition, CI was required to be $>310 \mathrm{~d}$, to avoid the inclusion of data from abortions or otherwise abnormally short pregnancies. This analysis included 3887 records (1784 cows) from the grazing herds and 16,461 records (8091 cows) from the conventional herds. the percentage of nonculled or noncensored records (obtained by dividing the numbers of usable CI records by the numbers of production records) was the same (63\%) in both environments.

For CI, only the genetic correlation between environments was of interest and regression on sire PTA was not possible because no genetic evaluation for CI is performed in Canada. The model applied was the same as that used for production traits (Equation [2]). In addition, the genetic parameters were reestimated using a model that considered phenotypic milk yield (305ME) as a covariate.

\section{Conformation}

Approximately 30 different conformation traits are recorded and evaluated in Canada, but many of these traits are correlated with each other. Therefore, we chose to concentrate our evaluation to the three traits that contribute directly to the Lifetime Profit Index, the official national selection index in Canada (Canadian Dairy Network, 2001). These traits are mammary system, feet and legs, and frame and capacity.

Although all of the herds participated in type classification, not all of the cows with production information had been classified. Only first-lactation records were used because classification in later lactations is not obligatory (i.e., data from later lactations are likely to be a biased sample) and only first-parity records contribute to the national genetic evaluation in Canada. For these reasons, the number of records for conformation were less than were available for production or reproduction. A total of 11,963 records were used, 2191 
from the grazing herds and 9772 from the conventional herds.

Following the approach used for yield traits, regression was first used to test for scaling effects. Genetic correlations then were calculated across the different environments to test for other forms of $\mathrm{G} \times \mathrm{E}$ that could cause reranking of sires. The effects included in the models were similar to those included in the national evaluation for type.

For the regression of cow phenotype on sire PTA for type, the model equation was,

$$
\mathrm{y}_{\mathrm{ijkl}}=\mathrm{SA}_{\mathrm{i}}+\mathrm{RC}_{\mathrm{j}}+\mathrm{HRC}_{\mathrm{k}}+\beta \mathrm{PTA}_{\mathrm{l}}+\mathrm{e}_{\mathrm{ijkl}}
$$

where $\mathrm{y}_{\mathrm{ijkl}}=$ conformation score of cow $\mathrm{l}$ in age at classification and stage of lactation group i, round-classifier group $\mathrm{j}$ (a different classifier visits the herd on each date of classification), and herd-round classifier group $\mathrm{k} ; \mathrm{SA}_{\mathrm{i}}=$ fixed effect of age and stage of lactation group $\mathrm{i}$ (4 age and 11 stage groups); $\mathrm{RC}_{\mathrm{j}}=$ fixed effect of roundclassifier $\mathrm{j} ; \mathrm{HRC}_{\mathrm{k}}=$ the fixed effect of herd-round-classifier $\mathrm{k} ; \beta$ coefficient of regression of the type scores on the PTA of the sire of cow $\mathrm{l}$; and $\mathrm{e}_{\mathrm{ijkl}}=$ random residual. The PTA for type in Canada are expressed on a standardized scale $(\mu=0$ and $\sigma=5)$, rather than on the phenotypic scale and, therefore, the regression coefficient was not expected to be 1.0. Student's $t$-test was used to determine whether the regression coefficients differed in the two environments.

The model equation for the estimation of heritabilities and genetic correlations across the two groups was,

$$
\mathrm{y}_{\mathrm{ijklt}}=\mathrm{SA}_{\mathrm{i}}+\mathrm{RC}_{\mathrm{j}}+\mathrm{HRC}_{\mathrm{k}}+\mathrm{A}_{\mathrm{lt}}+\mathrm{e}_{\mathrm{ijkl}} \text {, }
$$

where $\mathrm{y}_{\mathrm{ijklt}}=$ conformation score of cow $\mathrm{l}$ in environment $t$, in age and stage of lactation group $i$, round-classifier group $\mathrm{j}$, and herd-round-classifier group $\mathrm{k} ; \mathrm{SA}_{\mathrm{l}}, \mathrm{RC}_{\mathrm{j}}$, and $\mathrm{HRC}_{\mathrm{k}}$ are the same as in equation [3]; $\mathrm{A}_{\mathrm{lt}}=$ the random additive genetic effect of cow 1 in environment $\mathrm{t}$; and $\mathrm{e}_{\mathrm{ijkl}}=$ random residual .

\section{RESULTS}

Table 1 has means and standard deviations for the different traits for both environments. Not surprisingly, average production was greater in the conventionally managed herds than in the grazing herds $(P<0.01)$. The difference in milk yield between groups was 547 $\mathrm{kg}$, which was less than that $(1259 \mathrm{~kg})$ observed by Kearney et al. (2001b) for herds across the Eastern United States, but greater than that $(370 \mathrm{~kg})$ reported by Weigel et al. (1999) for herds in Wisconsin only. Fat and protein percentages were very similar across environments.

No significant difference was observed for CI. Kearney et al. (2001a) found that grazing herds in their study had slightly longer days open than did the control herds (154 to $148 \mathrm{~d}$ ), but attributed this difference to climatic effects as a greater proportion of their grazing herds were from the southern United States. Among the type traits, the means scores for mammary system and feet and legs were slightly but significantly greater $(P<0.01)$ within the grazing herds. The slight difference in udders may have been due to the slightly lower level of production in the grazing herds, as milk yield phenotypically is unfavorably correlated with traits such as fore udder attachment and udder depth (Short and Lawlor, 1992). The environment provided by grazing herds may have been favorable for feet and legs, as increased exposure to concrete has been shown to be associated with locomotive disorders (Galindo and Broom, 1993).

Means of EBV are in Table 2 for the traits for which EBV are calculated for cows in Canada. Means are significantly greater $(P<0.01)$ in the conventional herds for all traits except for frame and capacity. The differences in EBV explain approximately 15 to $20 \%$ of the differences in phenotypic means (Table 1) for yield traits and about $25 \%$ for type traits.

Table 3 has the regression coefficients of phenotypic values in the different environments on sire PTA. For

\begin{tabular}{|c|c|c|c|c|}
\hline \multirow[b]{2}{*}{ Trait } & \multicolumn{2}{|c|}{ Mean } & \multicolumn{2}{|c|}{ Standard deviation } \\
\hline & Conventional & Grazing & Conventional & Grazing \\
\hline Milk, kg & 9947 & 9400 & 1993 & 1606 \\
\hline Fat, kg & 361 & 343 & 73 & 61 \\
\hline Protein, kg & 316 & 297 & 60 & 49 \\
\hline Fat, \% & 3.67 & 3.67 & 0.52 & 0.44 \\
\hline Protein, $\%$ & 3.20 & 3.17 & 0.22 & 0.20 \\
\hline Calving interval, $\mathrm{d}$ & 408 & 407 & 71 & 69 \\
\hline Mammary system ${ }^{1}$ & 9.8 & 10.2 & 2.1 & 2.1 \\
\hline Feet and legs & 9.9 & 10.1 & 2.3 & 2.2 \\
\hline Frame and capacity & 11.7 & 11.8 & 2.4 & 2.4 \\
\hline
\end{tabular}

Table 1. Means and standard deviations of traits in grazing and conventional environments.

${ }^{1}$ Conformation traits are unitless. 
Table 2. Means and standard deviations of EBV for the various traits in the conventional and grazing environments.

\begin{tabular}{lccccc}
\hline & \multicolumn{2}{c}{ Mean } & & \multicolumn{2}{c}{ Standard deviation } \\
\cline { 2 - 3 } \cline { 2 - 3 } Trait & Conventional & Grazing & & Conventional & Grazing \\
\hline Milk, kg & 245 & 170 & & 811 & 557 \\
Fat, kg & 11.3 & 7.5 & 29.3 & 22.6 \\
Protein, kg $_{\text {Mammary system }}{ }^{1}$ & 9.5 & 0.0 & 23.9 & 16.0 \\
Feet and legs & 0.31 & 0.18 & & 0.48 & 0.31 \\
Frame and capacity & 0.23 & 0.42 & 0.49 & 0.44 \\
\hline
\end{tabular}

${ }^{1}$ Conformation traits are unitless.

all three yield traits, the regression coefficients were greater $(P<0.01)$ for the conventional herds, indicating a scaling effect, and suggesting that genetic differences among animals were more obvious in conventional herds. For the conventional herds, the regression coefficients were all significantly $(P<0.01)$ greater than 1.0. For the grazing herds, none of the coefficients were different from 1.0 .

Weigel et al. (1999) reported a significant scaling effect only for fat yield. Kearney et al. (2001b) reported regression coefficients less than 1 for all three yield traits in their grazing herds. Regression for PTA were closer to 1 within the grazing herds, suggesting that the current EBV for sires in Canada predict differences among daughters more accurately in grazing herds than in conventional herds, at least among herds defined as conventional in our study.

Veerkamp et al. (1995) reported a similar scaling effect when comparing the performance of selected and control lines of dairy cattle when fed two different TMR (neither including pasture) with either high or low levels of concentrate. The regression of actual performance on pedigree index was slightly lower for the cows on the low concentrate diet and on the high concentrate diet.

No scaling effects were observed for the type traits (Table 3). Regression coefficients for the type traits were

Table 3. Regression coefficients of yield and type traits on respective sire PTA in conventionally managed and grazing herds and standard errors $^{1}\left(\mathrm{SE}_{\text {diff }}\right)$ of the different between regression coefficients across groups.

\begin{tabular}{llll}
\hline & \multicolumn{2}{c}{ Regression coefficients } & \\
\cline { 2 - 3 } Trait & Conventional & Grazing & $\mathrm{SE}_{\text {diff }}$ \\
\hline Milk & $1.41^{* *}$ & 1.04 & 0.124 \\
Fat & $1.16^{* *}$ & 0.93 & 0.112 \\
Protein & $1.37^{* *}$ & 0.93 & 0.124 \\
Mammary system & 0.071 & 0.068 & 0.010 \\
Feet and legs & 0.071 & 0.085 & 0.010 \\
Frame and capacity & 0.104 & 0.095 & 0.011 \\
\hline
\end{tabular}

${ }^{1}$ Calculated as the square root of the sum of squares of the SE for the two regression coefficients.

$* * \beta$ significantly $>1.00(P<0.01)$. not expected to be 1 because EBV for type in Canada are transformed to a standard scale.

Estimates of heritabilities within each environment and genetic correlations across environments are in Table 4 for all nine traits evaluated. Heritabilities were generally lower than the grazing herds, but these differences were nonsignificant for most of the traits. For the yield traits, heritabilities fell in the general range of 0.35 to 0.40 for the conventional herds versus only 0.30 to 0.35 for the grazing herds. The increased estimates of heritability in the conventional herds coincide with the trends observed in regression coefficients (Table 3), which suggested that genetic differences among animals were expressed to a greater degree in the conventionally managed herds. Heritabilities of percentage traits were quite high but consistent with other estimates previously made on the Canadian Holstein population (Boettcher and Gibson, 1997; Z. Lui, 1996, unpublished technical report).

Effects of $\mathrm{G} \times \mathrm{E}$ on yield traits, as indicated by genetic correlations, were minor. The estimates of genetic correlations between the two management systems were around 0.90 or greater (Table 4) well above the threshold of 0.80 suggested by Robertson (1959). The genetic correlation was significantly $(P<0.01)$ less than unity only for fat yield. Fat yield also had the lowest genetic correlation in the study of Weigel et al. (1999), but was not different from 1 . They attributed apparent interactions for fat yield to inconsistency in pasture quality during summer months in Wisconsin. Average correlations reported by Kearney et al. (2001b) were similar for all three yield traits, falling between 0.88 (fat) and 0.91 (protein). Correlations for percentage traits were different from $1(P<0.05)$, but $\geq 0.92$.

Even less evidence of $\mathrm{G} \times \mathrm{E}$ was observed for reproduction and conformation traits. Some indication for $\mathrm{G} \times \mathrm{E}$ was observed for CI, as estimated heritability in grazing herds $(0.052)$ was nearly double that in conventional herds (0.027) and estimated genetic correlation across groups was only 0.64 . However, these differences were not significant $(P>0.05)$. When milk yield was added 
Table 4. Estimated heritabilities and genetic correlations (and their standard errors) for each trait in grazing and conventional management systems.

\begin{tabular}{lllllll}
\hline & \multicolumn{3}{c}{ Heritability } & & \multicolumn{2}{c}{ Genetic correlation } \\
\cline { 2 - 3 } Trait & Conventional & Grazing & $\mathrm{SE}_{\text {diff }}{ }^{1}$ & & $\mathrm{r}_{\mathrm{g}}$ & $\mathrm{SE}$ \\
\hline Milk & 0.37 & 0.31 & 0.02 & 0.93 & 0.04 \\
Fat & 0.39 & 0.35 & 0.03 & $0.88^{* *}$ & 0.04 \\
Protein & 0.36 & 0.30 & 0.02 & 0.94 & 0.04 \\
Fat \% & 0.67 & 0.70 & 0.03 & 0.92 & 0.02 \\
Protein $\%$ & 0.64 & 0.61 & 0.03 & $0.96^{* *}$ & 0.02 \\
Calving interval & 0.027 & 0.052 & 0.015 & 0.64 & 0.27 \\
Mammary system & 0.20 & 0.13 & 0.03 & 1.00 & $0.00^{2}$ \\
Feet and Legs & 0.17 & 0.17 & 0.03 & 0.97 & 0.10 \\
Frame and capacity & 0.34 & 0.27 & 0.04 & 0.90 & 0.06 \\
\hline
\end{tabular}

${ }^{1}$ Square root of the sum of squared standard errors of heritabilities in the two different environments.

${ }^{2}$ The $\mathrm{SE}=0.00$ is an artifact of the estimation procedure.

$* *$ Significantly different from $1(P<0.01)$.

to the model as a covariate, results changed very little except that the estimate of heritability in the grazing herds decreased to 0.036 .

Among the type traits, heritability for mammary system was greater in the conventional herds $(0.20 \mathrm{vs} 0.13)$ but genetic correlations between groups was 1.00 (SE of zero was an artifact of the estimation procedure). Perhaps the greater heritability in conventional herds was associated with higher mean production, and thus more stress on udder attachments. For feet and legs and frame and capacity, heritabilities were not different across environments and genetic correlations were not different from unity. These two results were interesting considering that 1) with respect to feet and legs, cows in grazing herds would generally have been exposed to much different environments (less concrete) from cows in the free-stall herds, and 2) for frame and capacity, the diets of cows in the grazing herds were expected to be quite different (more forage) from those in the freestall herds.

\section{DISCUSSION AND CONCLUSIONS}

In general, effects of $\mathrm{G} \times \mathrm{E}$ ere not great between conventional and grazing herds in Canada. The most profound observation was a scaling effect, in which phenotypic differences in yield between cows in conventional herds were approximately 20 to $40 \%$ greater than would have been predicted based on the EBV of their respective sires, while cattle from grazing herds would be expected to differ by about the same amount suggested by sire EBV. This scaling effect may have contributed to higher estimates of heritability in conventional herds. Genetic correlations of the same yield trait in different environments were not different from 1 , except for fat yield, which at 0.88 was still relatively high. For nonproduction traits effects of $\mathrm{G} \times \mathrm{E}$ were practically nonexistent.
A number of factors could explain this lack of observed $\mathrm{G} \times \mathrm{E}$. First, due to the cool climate and short growing seasons in Canada, the herds in this study practiced grazing for only about half of the year. The rest of the time feeding and management would be expected to be similar to the rest of Canada. Therefore, the two systems of management were not as extremely different as could be observed in another country such as the United States or between countries such as New Zealand and Canada. Secondly, all of the herds in both groups were enrolled in DHI and had primarily registered animals. These factors may suggest that other management practices were in common across groups. Another possibility is that expression of genes is not particularly different in quite diverse environments.

The level of $\mathrm{G} \times \mathrm{E}$ is too low to justify a separate national sire proving program for graziers, particularly in Canada, where, due to the climate, the number of producers practicing is relatively small. Weigel et al. (1999) concluded that a separate sire proving program for graziers would require sampling of 600 to 700 bulls per year to achieve the same genetic progress as using sires based on a national program for which results were genetically correlated by 0.90 . Weigel et al. (1999) also questioned the practice of using sires proven in typically grazing countries such as New Zealand or Ireland, because progeny testing programs in those countries are small and selection intensity would be lost.

One approach that could help resolve this problem is borderless international sire evaluations (Lohuis and Dekkers, 1998) in which herds are clustered (Weigel and Rekaya, 2000) by management practices, climate, and other factors instead of by country. Assuming that one of the clusters included primarily grazing herds and sires were progeny tested in multiple clusters, then perhaps graziers could select based on rankings for daughter performance in that cluster. However, adop- 
tion of such a system would require the navigation around various data recording, computational, and political obstacles.

\section{ACKNOWLEDGMENTS}

This research was supported in part by a grant from the Sustainable Agriculture Research and Education program of the USDA. In addition, authors would like to thank the farmers that participated in the study and the Canadian Dairy Network of Guelph, Ontario for providing the data.

\section{REFERENCES}

Boettcher, P. J., J. C. M. Dekkers, L. D. Warnick and S. J. Wells. 1998. Genetic analysis of clinical lameness in dairy cattle. J. Dairy Sci. 81:1148-1156.

Boettcher, P. J., and J. P. Gibson. 1997. Estimation of variance of maternal lineage effects among Canadian Holsteins. J. Dairy Sci. 80:2167-2176.

Cienfuegos-Rivas, E. G., P. A. Oltenacu, R. W. Blake, S. J. Schwager, H. Castillo-Juarez, and F. J. Ruiz. 1999. Interaction between milk yield of Holstein cows in Mexico and the United States. J. Dairy Sci. 82:2218-2223.

Canadian Dairy Network. 2001. Lifetime Profit Index formula. http:// www.cdn.ca/Articles/lifetime_profit_index.pdf (accessed October 2001).

Lohuis, M. M., and J. C. M. Dekkers. 1998. Merits of borderless evaluations. Proc. 6th World Congr. Genet. Appl. Livest. Prod., Armidale, Australia XXVI:169-172.
Galindo, F. A., and D. M. Broom. 1993. The relationships between social behaviour of dairy cows and the occurrence of lameness. J. Br. Cattle Vet. Assoc. 1:360-364.

Groeneveld, E., and A. Garcia-Cortes. 1998. VCE4.0, a covariance component package for frequentists and Bayesians. Proc. 6th World Congr. Genet. Appl. Livest. Prod. 27:455-456.

Kearney, J. F., M. M. Schutz, P. J. Boettcher, and K. A. Weigel. 2001a. Genotype by environment interaction for grazing versus confinement. II. Health and reproductive traits. J. Dairy Sci. (accepted).

Kearney, J. F., M. M. Schutz, P. J. Boettcher, and K. A. Weigel. 2001b. Genotype by environment interaction for grazing versus confinement. I. Production traits. J. Dairy Sci. (accepted).

Robertson, A. 1959. The sampling variance of the genetic correlation coefficient. Biometrics 15:469-485.

Short, T. H., and T. J. Lawlor. 1992. Genetic parameters of conformation traits, milk yield, and herd life in Holstein. J. Dairy Sci. 75:1987-1998.

Van Doormaal, B. J., and G. Kistemaker. 2001. Relating production proofs to average daughter yields. http://cgil.uoguelph.ca/dcbgc/ Agenda0109/agenda0109.htm (Accessed December 2001).

Veerkamp, R. F., G. Simm, and J. D. Oldham. 1995. Genotype by environmental interactions: experience from Langhill. Pages 5966 in Occasional Publication No. 19. Br. Soc. Anim. Sci.

Weigel, K. A., T. Kriegel, and A. L. Pohlman. 1999. Genetic analysis of Dairy Cattle Production Traits in a management intensive rotational grazing environment. J. Dairy Sci. 82:191-195.

Weigel, K. A., and R. Rekeya. 2000. A multiple-trait herd cluster model for international dairy sire evaluation. J. Dairy Sci. 83:815-821.

Weigel, K. A., R. Rekeya, N. R. Zwald, and W. F. Fiske. 2001. International genetic evaluation of dairy sires using a multiple-trait model with individual animal performance records. J. Dairy Sci. (submitted).

Welper, R. D. 2000. A futuristic look at the dairy cattle genetics industry. J. Dairy Sci. 83(Suppl. 1):6(Abstr.). 